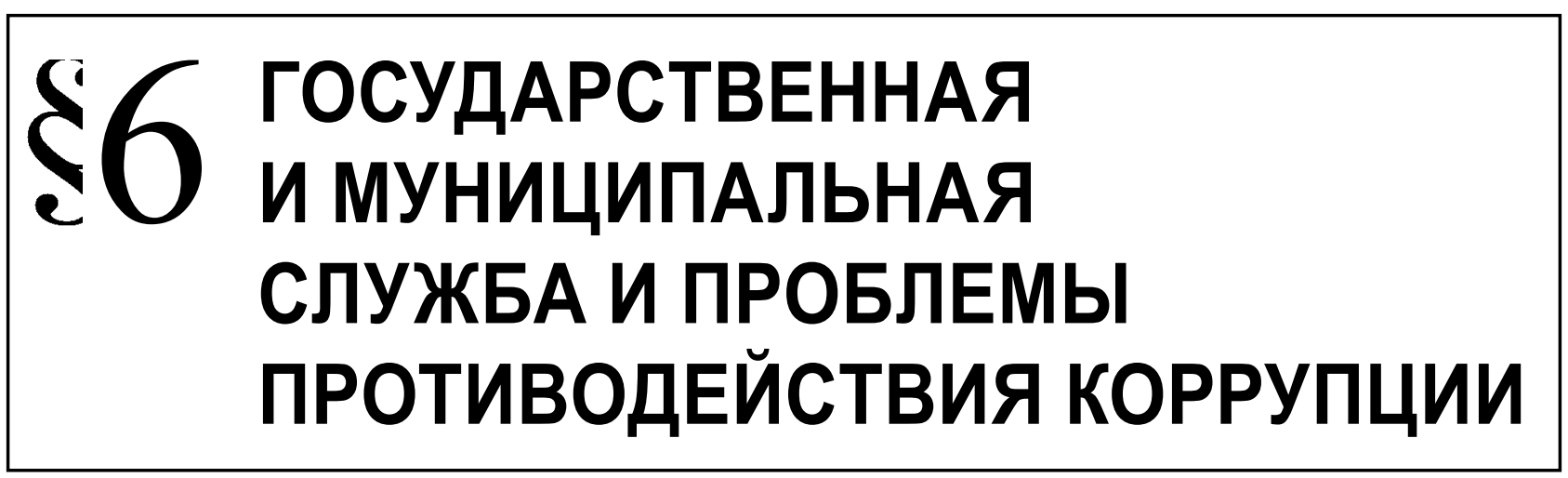

Кабанов П.А.

\title{
ПОЛНОМОЧИЯ СПЕЦИАЛИЗИРОВАННЫХ РЕГИОНАЛЬНЫХ СОВЕЩАТЕЛЬНЫХ АНТИКОРРУПЦИОННЫХ ОРГАНОВ В ОБЛАСТИ ИНФОРМАЦИОННОГО СОПРОВОЖДЕНИЯ ФОРМИРОВАНИЯ И РЕАЛИЗАЦИИ ГОСУДАРСТВЕННОЙ ПОЛИТИКИ ПРОТИВОДЕЙСТВИЯ КОРРУПЦИИ: АНАЛИЗ ПРАВОВОГО РЕГУЛИРОВАНИЯ И НЕКОТОРЫЕ НАПРАВЛЕНИЯ ЕГО СОВЕРШЕНСТВОВАНИЯ
}

\begin{abstract}
Аннотация: Предметом проведенного исследования выступают: а) основные положения региональных подзаконных нормативных правовых актов, регулирующих деятельность специализированных региональных совещательных, координационных, экспертных, консультативных, межведомственных антикоррупционных органов (советов и комиссий по противодействию коррупции) в области информационного сопровождения государственной политики противодействия коррупции на региональном уровне; б) основные формы или средства информационного сопровождения государственной политики противодействия коррупции на региональном уровне, закрепленные в нормативных правовых актах; в) основные меры направленные на совершенствование правового регулирования информационного сопровождения государственной политики противодействия коррупции на региональном уровне; В качестве основного метода научного исследования выступил сравнительно-правовой метод региональных нормативных правовых актов, регулирующих деятельности специализированных региональных совещательных антикоррупционных органов, а также общенаучные методы - анализ и синтез. Научная новизна проведенного исследования заключается в том, что впервые в российской юридической науке рассмотрено правовое регулирование деятельности специализированных региональных совещательных антикоррупционных органов в области информационного сопровождения государственной политики противодействия коррупции. Основные выводы: предложены меры по совершенствованию правового регулирования деятельности специализированных региональных совещательных антикоррупционных органов, которые заключаются: в формировании региональной антикоррупционной информационной политики; мониторинге эффективности системы информационного сопровождения региональной политики противодействия коррупции; выработке предложений по совершенствованию системы информационного сопровождения региональной политики противодействия коррупции.

Ключевые слова: коррупция, противодействие коррупции, антикоррупционная пропаганда, антикоррупционная политика, антикоррупционная реклама, антикоррупционная агитация, антикоррупционное информирование, информационная политика, государственная политика, информационное сопровождение.
\end{abstract}


И нформационное сопровождение формирования и реализации государственной региональной политики противодействия коррупции является сложной и ответственной задачей не только стоящей перед органами государственной власти, учреждениями массовой коммуникации, но специализированными совещательными, координационными, консультативными и экспертными антикоррупционными органами субъектов Российской Федерации. Эти региональные антикоррупционные органы, чаще всего, именуются Советами и/ или Комиссиями по противодействию коррупции (далее по тексту - специализированные региональные совещательные антикоррупционные органы - примечание автора - П.К.). Насколько эффективно данные антикоррупционные органы будут осуществлять свои полномочия в области информационного сопровождения региональной антикоррупционной политики, во многом зависит результативность противодействия коррупции в этих регионах. Как показывает региональная практика информационного сопровождения формирования и реализации антикоррупционной политики, в различных субъектах Российской Федерации она проходит с различной степенью интенсивности и результативности. Невзирая на важность и значимость данного направления деятельности специализированных региональных совещательных антикоррупционных органов, до настоящего времени российскими специалистами не проведено исследований правового регулирования таких полномочий этого субъекта региональной антикоррупционной политики и его влияния на состояние государственной политики противодействия коррупции в субъектах Российской Федерации. Имеющиеся исследования касаются, как правило, оценки общих полномочий специализированных региональных совещательных антикоррупционных органов, ${ }^{1}$ либо связаны с описанием правового регулирования и

\footnotetext{
1 Кабанов П.А. Республиканский совет по реализации антикоррупционной политики как субъект противодействия коррупции в Республике Татарстан: правовое положение, структура и компетенция // Следователь. - 2008. - №1. С.10-13; Сабитова Э.Н. Правовые и организационные основы деятельности специализированных совещательных, координационных, межведомственных, экспертных советов и комиссий по противодействию коррупции субъектов Российской Федерации // Взаимодействие институтов гражданского общества и органов местного самоуправления в сфере противодействия коррупции: материалы Всероссийского межвузовского круглого стола, г. Нижнекамск, 23 декабря 2011 г. / отв. ред. П.А. Кабанов, О.Д. Агапов. - Казань: Издво «Познание», 2012. - С.91-96.
}

организации отдельных форм информационного сопровождения государственной политики противодействия коррупции (антикоррупционной пропаганды ${ }^{2}$ и антикоррупционной рекламы ${ }^{3}$ ), в том числе и на региональном уровне. Имеются и работы рассматривающие вопросы информационного обеспечения государственной службы при осуществлении противодействия коррупции. ${ }^{4}$

Очевидно, что в целях повышения качества организации и правового регулирования информационного сопровождения региональной политики противодействия коррупции, необходимо на основе оценки опыта закрепления основных полномочий специализированных совещательных антикоррупционных органов субъектов Российской Федерации в сфере осуществления антикоррупционного информационного сопровождения исследование этого феномена. Для достижения данной цели нами проведено сравнительно-правовое исследование всех региональных подзаконных нормативных правовых актов, регулирующих деятельность специализированных региональных совещательных антикоррупционных органов, для того чтобы предложить некоторые меры по их совершенствованию информационного сопровождения региональной политики противодействия коррупции.

Проведенное нами сравнительно-правовое исследование региональных подзаконных нормативных правовых актов, регулирующих деятельность специализированных региональных совещатель-

\footnotetext{
2 Горшенков Г.Н. Антикоррупционная пропаганда как инструмент противодействия коррупции: понятие и сущностное содержание // Следователь. - 2010. — №10. - С.32-38; Его же. Антикоррупционная пропаганда: понятие и содержание // Актуальные проблемы экономики и права. - 2010. — №4 (16). С.39-46; Кабанов П.А. Антикоррупционная пропаганда как инструмент противодействия коррупции в Республике Татарстан: вопросы повышения качества правового регулирования // Право и политика. - 2013. - № 9. - С.1130-1138; Его же. Понятие и содержание антикоррупционной пропаганды как правовой категории в российском региональном антикоррупционном законодательстве // Административное и муниципальное право. - 2013. - №9. - С.878-884.

3 Кабанов П.А. Понятие антикоррупционной рекламы как правовой категории: региональный аспект // Административное и муниципальное право. - 2013. - №11. - С.10451051; Его же. Антикоррупционная реклама в Республике Татарстан как информационное средство противодействия коррупции: проблемы и перспективы // Актуальные проблемы экономики и права. - 2013. - №4. - С.38-45.

4 Костенников М.В., Куракин А.В., Кулешов Г.Н., Несмелов П.В. Административно-правовое регулирование информационного обеспечения государственной гражданской службы в контексте противодействия коррупции (ч. 1) // Административное и муниципальное право. - 2012. - 10. - С. $25-39$.
} 
ных антикоррупционных органов, показало, что из всех 83 субъектов Российской Федерации только в 25 или 30,1\% из них имеются нормы, отражающие их полномочия по информационному сопровождению формирования и реализации региональной антикоррупционной политики.

Анализ региональных подзаконных нормативных правовых актов о правовом регулировании деятельности совещательных антикоррупционных органов субъектов Российской Федерации показал, что информационное сопровождение антикоррупционной деятельности для них выступает в различных качествах. Для одних антикоррупционных органов оно закрепляется в качестве основной задачи, для других - провозглашается целью деятельности, для третьих является одной из функций, для четвертых - это их полномочия, для пятых - информационное сопровождение антикоррупционной деятельности сформулировано неопределенно.

В качестве основной задачи деятельности специализированных региональных совещательных антикоррупционных органов информационное сопровождение антикоррупционной деятельности предусмотрено в 15 или 60\% от общего количества таких действующих подзаконных нормативных правовых актов, в которых предусмотрены полномочия их деятельность по информационному обеспечению. Уполномоченными на то органами и должностными лицами субъектов Российской Федерации такие задачи поставлены перед специализированными региональными совещательными антикоррупционными органами Республики Татарстан, ${ }^{5}$ Республики Тыва, ${ }^{6}$ Пермского края, ${ }^{7}$ Амурской, ${ }^{8}$

\footnotetext{
5 О Совете при Президенте Республики Татарстан по противодействию коррупции: Указ Президента РТ от 21.02.2011 №УП-71 (в ред. от 30.12.2012 N УП-1145) // Ведомости Государственного Совета Татарстана. - 2011. —№1-2 (ІІ часть). Ст. 121.

6 О комиссии по противодействию коррупции в Республике Тыва: Указ Председателя Правительства РТ от 02.10.2008 г. № 221 (в ред. 21.12.2012 №317) // Тувинская правда. - 2008. - 7 октяб.

7 Об утверждении Положения о межведомственном совете по противодействию коррупции при Губернаторе Пермского края: Распоряжение Губернатора Пермского края от 29 июня 2010 года №94-p (в ред. от 05.03.2011)// http://www. admin.permkrai.ru/antikor/doc/?id=\&folder_id=516

8 О Совете при Губернаторе Амурской области по противодействию коррупции: Постановление Губернатора Амурской области от 20 апреля 2009 года №197 (в ред. от 29.10.2013 №308) //http://www.amurobl.ru/index. php? $\mathrm{m}=24598 \& \mathrm{rc}=50705 \& \mathrm{p}=52935$
}

Брянской, ${ }^{9}$ Вологодской, ${ }^{10}$ Курганской, ${ }^{11}$ Ростовской, ${ }^{12}$ Рязанской, ${ }^{13}$ Саратовской, ${ }^{14}$ Сахалинской, ${ }^{15}$ Свердловской, ${ }^{16}$ Тамбовской ${ }^{17}$ и Ульяновской ${ }^{18}$ областей, а также Еврейской автономной области. ${ }^{19}$

9 О Совете при Губернаторе Брянской области по противодействию коррупции: Постановление Администрации Брянской области от 27 августа 2009 года №909 (в ред. от 15.10.2010) //http://www.regionz.ru/index.php?ds=362943

10 О создании Совета по противодействию коррупции в Вологодской области: Постановление Губернатора Вологодской области от 13 мая 2010 года № 239 (в ред. от 13.12.2012 N 661) //Красный Север. - 2010. - 18 мая.

11 О мерах по противодействию коррупции в Курганской области: Указ Губернатора Курганской области от 12 октября 2008 года №406 (ред. от 8 08. 2011 г. №262)// http://www. oblduma.kurgan.ru/common/doc/projects/presidents_initiative/ corruption/U_406.doc

12 О комиссии по противодействию коррупции в Ростовской области: Постановление Правительства Ростовской области от 27 октября 2011 г. № 88 (в ред. от 27.03.2013 №169) // http://www.donland.ru/Default.aspx?pageid=93129

13 О создании Совета по противодействию коррупции при Губернаторе Рязанской области: Распоряжение Губернатора Рязанской области от 13.11.2009 № 323-рг (в ред. от 20.12.2012) // Рязанские ведомости. - 2009. - 17 нояб.

14 О создании межведомственного координационного Совета по противодействию коррупции при Губернаторе Саратовской области: Постановление Губернатора Саратовской области от 01.11.2013 N 430 // Собрание законодательства Саратовской области. - 2013. - №45, октябрь-ноябрь, (выход в свет 07.11.2013).

15 О совете при Губернаторе Сахалинской области по противодействию коррупции в органах исполнительной власти Сахалинской области: Указ губернатора Сахалинской области от 28 мая 2010 г. № 20 //Губернские ведомости. - 2010. - 11 июня.

16 О совете при Губернаторе Свердловской области о противодействии коррупции: Указ Губернатора Свердловской области от 9 сентября 2008 года №982-УГ (в ред. от 06.02.2013) // Собрание законодательства Свердловской области. - 2008. — №9. - Ст. 1358.

17 О межведомственном совете по противодействию коррупции в исполнительных органах государственной власти: Постановление Администрации Тамбовской области от 28 июля 2008 года №913 (в ред. от 05.03.2013) // www.tambov.gov. $\mathrm{ru} / \mathrm{org} / 818 / 2027 . \mathrm{html}$

18 О Координационном совете по реализации антикоррупционной политики в Ульяновской области: Постановление Губернатора Ульяновской области от 19 апреля 2007 года №27 (в ред. от 27.10.2008 № 86) // Ульяновская правда. 2007. - 25 апр.

19 О Совете при Губернаторе Еврейской автономной области по противодействию коррупции: Постановление губернатора Еврейской автономной области от 6 марта 2009 года №47 (в ред. от 16.10.2012 N 248) // Собрание законодательства ЕАО. - 2009. - № 11. - Ст. 3643. 
В качестве целей деятельности специализированных региональных совещательных антикоррупционных органов по информационному сопровождению антикоррупционной деятельности имеются упоминания в нормативных правовых актах только двух регионов - Астраханской ${ }^{20}$ и Пензенской ${ }^{21}$ областей.

Специальными полномочиями по информационному сопровождению антикоррупционной деятельности подзаконными нормативными правовыми актами наделены специализированные региональные совещательные антикоррупционные органы Республики Калмыкии ${ }^{22}$ и Орловской области. ${ }^{23}$

В отдельных субъектах Российской Федерации специализированные региональные совещательные антикоррупционные органы наделены функциями по информационному сопровождению антикоррупционной деятельности. В числе таких региональных совещательных антикоррупционных органов оказались Совет при Главе Чеченской Республики по противодействию коррупции, ${ }^{24}$ Комиссии по противодействию коррупции в Ленинградской области ${ }^{25}$ и Комиссии по противодействию коррупции в Новгородской области. ${ }^{26}$ Еще в трех специали-

20 Об утверждении Положения о межведомственном координационном совете при Губернаторе Архангельской области по противодействию коррупции: Постановление Главы администрации Архангельской обл. от 26.12.2008 N 100 (ред. от 09.03.2010)

21 О Совете при Правительстве Пензенской области по противодействию коррупции: Постановление Правительства Пензенской области от 19 августа 2008 г. №521-пП (в ред. от 20.09.2012) // Пензенские губернские ведомости. 2008. - 2 сентяб. N 39. - С.59.

22 О Комиссии по предупреждению и противодействию коррупции в Республике Калмыкия: Указ Главы Республики Калмыкия от 15 сентября 2008 г. № 162 (в ред. от 05.06.2013 №72) // http://www.corrupcii.net/index.php?option=com_conte nt\&task=view\&id=145\&Itemid=13

23 О мерах по противодействию коррупции в Орловской области: Указ Губернатора Орловской области от 09.03.2010 N 60 (ред. от 23.01.2013)

24 О мерах по противодействию коррупции в государственных органах Чеченской Республики: Указ Президента Чеченской Республики от 25.09.2008 №300 (в ред. от 21.11.2008 N 372) // Вести Республики. - 2008. - 21 октяб.

25 Об образовании Комиссии по предупреждению и противодействию коррупции в Ленинградской области: Постановление Губернатора Ленинградской области от 30 сентября 2008 года №196 (в ред. от 30.09.2013) // Вестник Правительства Ленинградской области. - 2008. - 14 нояб.

26 О комиссии по противодействию коррупции в Новгородской области: Указ Губернатора Новгородской области от зированных региональных совещательных антикоррупционных органах (Кировская ${ }^{27}$ и Липецкая ${ }^{28}$ области, Ямало-Ненецкий автономный округ ${ }^{29}$ ) информационное сопровождение антикоррупционной деятельности сформулировано неопределенно, как необходимая часть противодействия коррупции для достижения конечного результата - снижения уровня коррупции в регионе.

Как нам представляется, наибольший интерес вызывают формы информационного сопровождения антикоррупционной деятельности, осуществляемые специализированными региональными совещательными антикоррупционными органами. Здесь наибольшей популярностью пользуется такая форма или средство информационного сопровождения антикоррупционной деятельности как антикоррупционная пропаганда. Именно в 14 нормативных правовых актах, регулирующих деятельность специализированных региональных совещательных антикоррупционных органов, она предусмотрена в качестве цели, задачи, функции или полномочия этих органов. К иным полномочиям деятельности этих органов относится антикоррупционное информирование населения, именуемое в региональных нормативных правовых актах словосочетаниями «информирование населения о ходе борьбы с коррупцией», ${ }^{30}$ «реализация антикоррупционных информационно-пропагандистских мер», ${ }^{31}$ «выступление в СМИ по вопро-

06.07.2009 № 139 (в ред. от 11.03.2013 N 48) //Новгородские ведомости.- 2009. - 10 июля.

27 О межведомственной комиссии при Губернаторе Кировской области по противодействию коррупции в Кировской области: Указ Губернатора Кировской области от 18.09.2009 № 81(в ред. 02.07.2010 г. №64)// Вести. Киров. - 2009. - 29 сентяб.

28 О координационном совете Липецкой области по противодействию коррупции: Распоряжение администрации Липецкой области от 25.09.2008 № 417-р (в ред. от 12.12.2012 №658-p)// http://www.uao-lipetsk.ru/492/494/234.htm

29 О межведомственном совете при Губернаторе Ямало-Ненецкого автономного округа по противодействию коррупции: Постановление Губернатора ЯНАО от 25 ноября 2011 года №198-ПГ (в ред. от 19.06.2012) // Красный Север. 2011. - 29 нояб. (спецвыпуск № 74)

30 О мерах по противодействию коррупции в Орловской области: Указ Губернатора Орловской области от 09.03.2010 N 60 (ред. от 23.01.2013)

31 О создании Совета по противодействию коррупции в Вологодской области: Постановление Губернатора Вологодской области от 13 мая 2010 года № 239 (в ред. от 13.12.2012 N 661) //Красный Север. - 2010. - 18 мая. 
сам противодействия коррупции», 32 «освещение в СМИ деятельность Комиссии по противодействию коррупции» ${ }^{33}$ или «информационное обеспечение реализации Плана противодействия коррупции». ${ }^{34}$

В качестве средств информационного сопровождения антикоррупционной деятельности в региональных нормативных правовых актах предусмотрено осуществление специализированными региональными совещательными антикоррупционными органами антикоррупционной агитации, именуемой громоздким словосочетанием «агитация в целях формирования нетерпимого отношения к коррупции».35

Пожалуй, самой экзотической для большинства специализированных региональных совещательных антикоррупционных органов, но крайне важной функцией наделена Комиссия по противодействию коррупции в Республике Тыва. Эта функция именуется мониторингом сообщений в средствах массовой информации о фактах коррумпированности должностных лиц органов государственной власти и местного самоуправления Республики Тыва. ${ }^{36}$ Данное направление деятельности иногда именуется отечественными специалистами более ёмким термином - «антикоррупционный мониторинг в сфере массовой коммуникации». ${ }^{37}$

32 Об образовании Комиссии по предупреждению и противодействию коррупции в Ленинградской области: Постановление Губернатора Ленинградской области от 30 сентября 2008 года №196 (в ред. от 30.09.2013) // Вестник Правительства Ленинградской области. - 2008. - 14 нояб.

33 О Комиссии по предупреждению и противодействию коррупции в Республике Калмыкия: Указ Главы Республики Калмыкия от 15 сентября 2008 г. № 162 (в ред. от 05.06.2013 №72) // http://www.corrupcii.net/index.php?option=com_conte nt\&task=view\&id $=145 \&$ Itemid $=13$

34 О межведомственном совете по противодействию коррупции в исполнительных органах государственной власти: Постановление Администрации Тамбовской области от 28 июля 2008 года №913 (в ред. от 05.03.2013) // www.tambov.gov. ru/org/818/2027.html

35 О создании Совета по противодействию коррупции при Губернаторе Рязанской области: Распоряжение Губернатора Рязанской области от 13.11.2009 № 323-рг (в ред. от 20.12.2012) // Рязанские ведомости. - 2009. - 17 нояб.

36 О комиссии по противодействию коррупции в Республике Тыва: Указ Председателя Правительства РТ от 02.10.2008 г. № 221 (в ред. 21.12.2012 №317) // Тувинская правда. — 2008. 7 октяб.

37 Горшенков А.Г. Антикоррупционный мониторинг в сфере массовой коммуникации // Актуальные проблемы экономики и права. - 2009. - №4 (12). - С.42-44.
Проведенное исследование показывает, что для разных специализированных региональных совещательных антикоррупционных органов не одинаково выглядит их объем полномочий, которыми они наделены уполномоченными на то органами и должностными лицами субъектов Российской Федерации. В одних регионах специализированные региональные совещательные антикоррупционные органы должны подготавливать и вносить предложения по формированию отдельных направлений системы информационного сопровождения антикоррупционной деятельности уполномоченным на то государственным органам и/или их должностным лицам (Республика Татарстан, Пермский край, Курганская и Саратовская области, Ямало-Ненецкий автономный округ). В других деятельность специализированных региональных совещательных антикоррупционных органов сводится к содействию по формированию такой системы (Амурская, Брянская, Сахалинская, Свердловская и Ульяновская области). Имеются регионы, где специализированные региональные совещательные антикоррупционные органы обязаны - разрабатывать систему мер антикоррупционного информирования и её реализовывать (Пензенская и Орловская области). В отдельных регионах специализированные региональные совещательные антикоррупционные органы должны - участвовать в организации работы по осуществлению лишь антикоррупционной пропаганды (Новгородская область) либо заниматься информационным обеспечением реализации государственной политики в области противодействия коррупции (Еврейская автономная область). По неизвестным причинам вне поля зрения региональных органов государственной власти оказалась функция по мониторингу эффективности информационного обеспечения государственной политики противодействия коррупции на региональном уровне, полномочия по осуществлению которой можно было бы закрепить за специализированными региональными совещательными антикоррупционными органами.

Анализ системы полномочий региональных специализированных совещательных антикоррупционных органов с учетом их статуса «координационных», «экспертных» и «совещательных», а также их правового положения позволяет нам предположить, что необходимо четко сформулировать полномочия этих органов в сфере информационного сопровождения региональной антикоррупционной политики и закрепить их в соответствующих нормативных правовых актах. 
На наш взгляд, основное предназначение региональных специализированных совещательных антикоррупционных органов заключается в зависимости от состояния информационной составляющей региональной антикоррупционной политики. Если информационная составляющая антикоррупционной политики находится в неразработанном состоянии, то в активном участии по формированию организационно-правовых основ и/или Концепции информационного обеспечения региональной государственной политики в области противодействия коррупции. Если уже организационно-правовые основы обеспечения региональной государственной политики в области противодействия коррупции или такая концепция разработана и реализуется, то в антикоррупционном мониторинге за качеством её реализации и выработке предложений по её совершенствованию и повышению эффективности.

Следовательно, полномочия специализированных региональных совещательных антикоррупци- онных органов по информационному сопровождению региональной антикоррупционной политики должны заключаться в следующем. Во-первых, в выработке предложений по созданию системы информационного сопровождения региональной политики противодействия коррупции и закреплении этого в региональных нормативных правовых актах. Во-вторых, в оценке эффективности системы информационного сопровождения региональной политики противодействия коррупции. В-третьих, в выработке предложений по совершенствованию системы информационного сопровождения региональной политики противодействия коррупции.

На наш взгляд, предложенные нами меры могут потребовать в ближайшее время изменить содержание и объем полномочий специализированных региональных совещательных антикорррупционных органов, а также позволить отечественным специалистам начать активную разработку новейшего научного направления антикоррупционной информационной политики.

\section{Библиография:}

1. Кабанов П.А. Республиканский совет по реализации антикоррупционной политики как субъект противодействия коррупции в Республике Татарстан: правовое положение, структура и компетенция // Следователь. - 2008. - №1. - С.10-13.

2. Сабитова Э.Н. Правовые и организационные основы деятельности специализированных совещательных, координационных, межведомственных, экспертных советов и комиссий по противодействию коррупции субъектов Российской Федерации // Взаимодействие институтов гражданского общества и органов местного самоуправления в сфере противодействия коррупции: материалы Всероссийского межвузовского круглого стола, г. Нижнекамск, 23 декабря 2011 г. / отв. ред. П.А. Кабанов, О.Д. Агапов. — Казань: Изд-во «Познание», 2012. - С.91-96.

3. Горшенков Г.Н. Антикоррупционная пропаганда как инструмент противодействия коррупции: понятие и сущностное содержание // Следователь. - 2010. - №10. - С.32-38.

4. Горшенков Г.Н. Антикоррупционная пропаганда: понятие и содержание // Актуальные проблемы экономики и права. — 2010. — №4 (16). - С.39-46.

5. Кабанов П.А. Антикоррупционная пропаганда как инструмент противодействия коррупции в Республике Татарстан: вопросы повышения качества правового регулирования // Право и политика. 2013. — № 9. - С.1130-1138.

6. Кабанов П.А. Понятие и содержание антикоррупционной пропаганды как правовой категории в российском региональном антикоррупционном законодательстве // Административное и муниципальное право. - 2013. — №9. - С.878-884.

7. Кабанов П.А. Понятие антикоррупционной рекламы как правовой категории: региональный аспект // Административное и муниципальное право. - 2013. - №11. - С.1045-1051.

8. Кабанов П.А. Антикоррупционная реклама в Республике Татарстан как информационное средство противодействия коррупции: проблемы и перспективы // Актуальные проблемы экономики и права. - 2013. - №4. - С.38-45.

9. Горшенков А.Г. Антикоррупционный мониторинг в сфере массовой коммуникации // Актуальные проблемы экономики и права. - 2009. - №4 (12). - С.42-44.

10. Костенников М.В., Куракин А.В., Кулешов Г.Н., Несмелов П.В. Административно-правовое регулирование информационного обеспечения государственной гражданской службы в контексте 
Административное и муниципальное право 1 (73) • 2014

противодействия коррупции (ч. 1) // Административное и муниципальное право. - 2012. 10. - С. $25-39$.

\section{References (transliterated):}

1. Kabanov P.A. Respublikanskii sovet po realizatsii antikorruptsionnoi politiki kak sub"ekt protivodeistviya korruptsii v Respublike Tatarstan: pravovoe polozhenie, struktura i kompetentsiya // Sledovatel'. — 2008. — №1. - S.10-13.

2. Sabitova E.N. Pravovye i organizatsionnye osnovy deyatel'nosti spetsializirovannykh soveshchatel'nykh, koordinatsionnykh, mezhvedomstvennykh, ekspertnykh sovetov i komissii po protivodeistviyu korruptsii sub"ektov Rossiiskoi Federatsii // Vzaimodeistvie institutov grazhdanskogo obshchestva i organov mestnogo samoupravleniya $\mathrm{v}$ sfere protivodeistviya korruptsii: materialy Vserossiiskogo mezhvuzovskogo kruglogo stola, g. Nizhnekamsk, 23 dekabrya 2011 g. / otv. red. P.A. Kabanov, O.D. Agapov. — Kazan': Izd-vo «Poznanie», 2012. - S.91-96.

3. Gorshenkov G.N. Antikorruptsionnaya propaganda kak instrument protivodeistviya korruptsii: ponyatie i sushchnostnoe soderzhanie // Sledovatel'. — 2010. — №10. - S.32-38.

4. Gorshenkov G.N. Antikorruptsionnaya propaganda: ponyatie i soderzhanie // Aktual'nye problemy ekonomiki i prava. - 2010. - №4 (16). - S.39-46.

5. Kabanov P.A. Antikorruptsionnaya propaganda kak instrument protivodeistviya korruptsii v Respublike Tatarstan: voprosy povysheniya kachestva pravovogo regulirovaniya // Pravo i politika. — 2013. — № 9. — S.1130-1138.

6. Kabanov P.A. Ponyatie i soderzhanie antikorruptsionnoi propagandy kak pravovoi kategorii v rossiiskom regional'nom antikorruptsionnom zakonodatel'stve // Administrativnoe i munitsipal'noe pravo. — 2013. — №9. - S.878-884.

7. Kabanov P.A. Ponyatie antikorruptsionnoi reklamy kak pravovoi kategorii: regional'nyi aspekt // Administrativnoe i munitsipal'noe pravo. - 2013. — №11. - S.1045-1051.

8. Kabanov P.A. Antikorruptsionnaya reklama $\mathrm{v}$ Respublike Tatarstan kak informatsionnoe sredstvo protivodeistviya korruptsii: problemy i perspektivy // Aktual'nye problemy ekonomiki i prava. — 2013. №4. - S.38-45.

9. Gorshenkov A.G. Antikorruptsionnyi monitoring v sfere massovoi kommunikatsii // Aktual'nye problemy ekonomiki i prava. - 2009. - №4 (12). - S.42-44.

10. Kostennikov M.V., Kurakin A.V., Kuleshov G.N., Nesmelov P.V. Administrativno-pravovoe regulirovanie informatsionnogo obespecheniya gosudarstvennoi grazhdanskoi sluzhby $\mathrm{v}$ kontekste protivodeistviya korruptsii (ch. 1) // Administrativnoe i munitsipal'noe pravo. - 2012. - 10. - C. $25-39$. 